\title{
GOOD HYGIENE PRACTICES AS AN IMPORTANT PROGRAM FOR SAFETY OF
}

\section{FINAL PRODUCTS}

\author{
*Ljubica TRAJKOSKA ${ }^{1}$, Maja TRAJANOSKA ${ }^{1}$, Biljana TRAJKOVSKA ${ }^{1}$, \\ Ljupche KOCHOSKI ${ }^{\mathbf{1}}$, Vesna KARAPETKOVA-HRISTOVA ${ }^{\mathbf{1}}$
}

${ }^{1}$ Faculty of Biotechnical Scieneces, University St. Kliment Ohridski, ljubicaatrajkoska@gmail.com St. Partizanska bb,Bitola, North Macedonia, info@,fbn.uklo.edu.mk

*Corresponding author

Received $25^{\text {th }}$ October 2020, accepted 30 ${ }^{\text {th }}$ March 2021

\begin{abstract}
In order to meet the requirements regarding food safety, in addition to the HACCP system, food operators are required to adopt, implement and document Good Hygiene Practice (GMP), Good Manufacturing Practice (GMP), Standard Operating Procedures (SOP) and Standard Sanitary Operating Procedures (SSOP). Therefore, the purpose of our research was to determine the importance of implemented hygienic and manufacturing practices in the meat industry in the municipality of Prilep. Analysis of the sensory, physicochemical and microbiological parameters of water, as well as the presence of Listeria monocytogenes on the contact surface and in thin sausage (vacuum packed) was performed. The results of the water analysis show that it is safe and does not lead to additional contamination of sausages. In addition, the absence of Listeria monocytogenes is a result of well-established practices regarding the microbiological quality of sausages.
\end{abstract}

Keywords: GHP, GMP, security, sausage.

\section{Introduction}

Today's urbanization conditions, as well as global environmental pollution, make food safety a major global problem [1], while protecting food sources is imperative for protecting human health [2]. In the food sector the implementation of Good Hygiene Practice (GHP) and Good Manufacturing Practice (GMP) ensures the creation and maintenance of favorable production conditions [3], with the aim of improving the safety of the finished product [4].

Meat is a food that is an integral part of daily diet, but in well-developed countries its use is limited due to health risks [5], and because it easily becomes subject to microbial contamination [6]. The most important microbiological causes of meat contamination are: Listeria monocytogenes, Clostridium botulinum, Salmonella spp., Escherichia coli and
Yersinia enterocolitica [7]. Listeria monocytogenes is the only psychotropic anaerobic/ facultative anaerobic bacterium that causes contamination of thermally unprocessed meat and all processed meat products obtained from it, including readyto- eat food [8].

\section{Matherials and methods}

The research was conducted in a meat industry (facility for production of smoked meat products, meat preparations and minced meat) in the Prilep region for a period of one year. Samples were taken ones a month from contact surface $(\mathrm{N}=12)$, finished product $(\mathrm{N}=12)$ and water $(\mathrm{N}=12)$. The water tests included analyzes of sensory, physicochemical, and microbiological parameters. Samples of water were taken in glass sterile bottles. Chemical parameters pH (ISO 10523: 2012), nitrates (ISO 6777: 1993) and 
ammonium ion (ISO 7393-3: 1990) were examined. Microbiological analysis of $E$. coli (ISO 9308-1), Enterococci (ISO 78992), Pseudomonas aeruginosa (ISO 162666) and total number of microorganisms at $22^{\circ} \mathrm{C}$ (ISO 6461-2) and at $37^{\circ} \mathrm{C}$ (ISO 6222) were performed. The methods used are in accordance with Rulebook on Water Safety (Official Gazette of the Republic of Macedonia no. 46/2008).

Analyzes for the presence of Listeria monocytogenes on the contact surface and in thin sausage (vacuum packed) were performed using the standard MAK EN ISO 11290-1.2 method. Representative samples for examination of the microbiological safety of the contact surface were taken from $50 \mathrm{~cm}^{2}$ of contact surface. For sausages analysis were taken five units $(25 \mathrm{~g})$ of one sample. For both analyzes the samples were placed in clean, sterile containers that provide adequate protection against further contamination.

\section{Results and discussion}

The quality of water must comply with the standards for safe drinking water, because can be an ingredient in many foods [9]. According to the results shown in table 1, it can be observed that the analyzed parameters are within the permissible limits in accordance with the approval with the authorization [10]. According to [11] the low values obtained for the presence of nitrates and residual chlorine are indicators of good water quality and the absence of pathogenic microorganisms (Table 1).

Table 1

Physicochemical and microbiological analysis of water

\begin{tabular}{|l|c|c|}
\hline \multicolumn{1}{|c|}{ Parameters tested (N=12) } & Results output & Permissible limits \\
\hline $\mathrm{pH}$ & 7.3 & $6.5-9.5$ \\
\hline Nitrates (mg / L) & 0.2 & 50 \\
\hline Chlorine (mg / L) & 0.3 & $0.3-0.5$ \\
\hline E. coli & $0 / 100 \mathrm{ml}$ & $0 / 100 \mathrm{ml}$ \\
\hline Enterococci & $0 / 250 \mathrm{ml}$ & $0 / 250 \mathrm{ml}$ \\
\hline Pseudomonas aeruginosa & $0 / 250 \mathrm{ml}$ & $0 / 250 \mathrm{ml}$ \\
\hline Total number of microorganisms at $22^{\circ} \mathrm{C}$ & $5 / 1 \mathrm{ml}$ & $100 / 1 \mathrm{ml}$ \\
\hline Total number of microorganisms at $37^{\circ} \mathrm{C}$ & $0 / 20 \mathrm{ml}$ & $20 / 1 \mathrm{ml}$ \\
\hline
\end{tabular}

The most important sensory parameters investigated in water are color, taste, and odor [12]. Accordingly, our results indicate that water meets the requirements for use in the food sector as there are no significant changes in it. Contact surfaces in food industry are particularly important as a potential source of contamination. The quality, durability and safety of meat products largely depend on cleaning, washing, and disinfecting equipment and contact surfaces [13]. Specifically, if the equipment is contaminated with Listeria monocytogenes it may be the reason for sausage contamination as a final product during production [14].

Ljubica TRAJKOSKA, Maja TRAJANOSKA, Biljana TRAJKOVSKA, Ljupche KOCHOSKI, Vesna KARAPETKOVA-HRISTOVA, Good hygiene practices as an important program for safety of final products, Food and Environment Safety, Volume XX, Issue 1 - 2021, pag. 49 - 52 
Table 2

Results of the analyzed swabs of the contact surface (slides) and thin sausage (vacuum packed) for the presence of $L$. monocytogenes

\begin{tabular}{|c|c|}
\hline Parameters tested $(\mathrm{N}=12)$ & Results output \\
\hline L. monocytogenes in contact surface swabs & Negative \\
\hline L. monocytogenes in thin sausage (vacuum packed) & Negative \\
\hline
\end{tabular}

The absence of Listeria monocytogenes from stainless steel equipment (Table 2) was determined; the results indicated a well-implemented GHP [15]. Starting from the fact that each meat industry is obliged to make a microbiological analysis on the presence of Listeria monocytogenes in the finished product in accordance with the marketing authorization [16], the contaminated meat products with this bacterium represent a serious public health hazard [7].

According to [8] the absence of Listeria monocytogenes in the final product is due to the effectiveness of the fermentation, maturation and drying of the products. Also, absence of Listeria monocytogenes from the equipment (Table 2) and appropriate application of the technological procedure decrease in the contamination rate [17].

Final products are likely to be contaminated with Listeria monocytogenes during storage time if hygienic conditions are unsatisfactory [18] which in turn constitutes a risk of production and sales losses.

\section{Conclusion}

In the context of the above results, it can be concluded that well-implemented GHP and GMP in the food industry result in the production of a safe product. In order to get a safe food product we must take care of hygiene throughout the production process. In the case of deviations from the prescribed norms in accordance with the veterinary measures and controls for the protection of public health, a program of corrective action aimed at the introduction and implementation of corrective measures to eliminate the causes of non-compliance should be implemented.

\section{References}

[1]. J. C. H. GODFRAY, P. AVEYARD, T. GARNETT, W. J. HALL, J. T. KEY, J. LORIMER, T. R. PIERREHUMBERT, P. SCARBOROUGH, M. SPINGMANN \& A. S. JEB. Meat consumption, health, and the environment. DOI:10.1126/science.aam5324 (2018)

[2]. M. MINEHAN. Green, Healthy and Eat Meat? (A mixed methods investigation into how meat is used and viewed by meat - eaters in Australia) (2013)

[3]. Asian Productivity Organization - APO. Quality Enhance in Food Processing Through HACCP. ISBN:92-833-7041-4. (2005)

[4]. J. KNAFLEWSKA \& E. POSPIECH. Quality Assurance Systems in Food Industry and health security of food. Acta Sci. Pol., Technol. Aliment. 6(2), 75-85, (2007)

[5]. J. BEREZNICKA \& T. PAWLONKA. Meat consumption as an indicator of economic wellbeing - case study of a developed and developing economy. Acta Sci. Pol. Oeconomia 17 (2), 17-26, (2018)

[6]. SOEPRANIANONDO, K. D. WARDHANA, BUDIARTO \& DIYANTORO. Analysis of bacterial contamination and antibiotic residue of beef meat from city slaughterhouses in East Java

Ljubica TRAJKOSKA, Maja TRAJANOSKA, Biljana TRAJKOVSKA, Ljupche KOCHOSKI, Vesna KARAPETKOVA-HRISTOVA, Good hygiene practices as an important program for safety of final products, Food and Environment Safety, Volume XX, Issue 1 - 2021, pag. 49 - 52 
Province, Indonesia. Vet World. 2019; 12(2), 243-248, (2019)

[7]. M. PAL, F. D. DANA, A. PATEL \& Y. AYELE. Microbiological and hygienic quality of Meat and Meat Products. Beverage and Food World. 45(5) (2018)

[8]. N. ZDOLEC, L. KOZACINSKI, M. HADZIOSMANOVIC, Z. CVRTILA, \& I. FILIPOVIC. Inhibition of Listeria monocytogenes growth in dry fermented sausages. Veterinarski arhiv. 77 (6), 507-514, (2007)

[9]. WUJIE, ZHUFEI \& XUJING. The influence of Water Quality on Food Quality and the Treatment of Water for Food Processing. International Conference on Environmental Science and Information Application Technology. 10, 2671-2676, (2011)

[10]. Official Gazette of the Republic of Macedonia no. 46/2008 (Rulebook on Water Safety)

[11]. O. A. FADRIAN \& M. S. Mammba. Analysis of nitrates and nitrites in some water and factory effluent samples from some cities in Swaziland. Bull. Chem. Soc. Ethipo. 19(1), 35-44, (2004)

[12].S. GRUJIC, B. ODZAKOVIC \& M. CIGANOVIC. Sensory analysis as a tool in the new product development. Proceedings of II International Congress Food Technology Quality and Safety - Novi Sad, Serbia, 325-330, (2014)

[13]. G. P. CRANDALL, A. C. O'BRYAN, M. E. MARTIN, H. M. KUEFNER, S. PENDLETON, M. E. SHANNON, A. J. MARCY \& C. S. RICKE. Efficacy of Cleaning and Sanitizing Agents against Attached Listeria monocytogenes on Meat Slicer Components. Food Protection Trends, 32(2), 68-72, (2012)
[14]. B. R. TOMPKIN. Control of Listeria monocytogenes in the Food-Processing Environment. Journal of Food Protection. 65(4), 709-725, (2002)

[15]. A. R. BAFANDA, S. KHANDI, U. SHEIKH, A. MINHAJ KHATEEB \& T. PILLI. Meat Hygiene and Associated Health Hazards Awareness among Consumers of Jammu District of Jammu and Kashmir. Current Journal of Applied Science and Technology. 23. 1-11. 10.9734/CJAST/2017/36045, (2017)

[16]. Official Gazette of the Republic of Macedonia no. 100/2013 (Rulebook on Special Requirements Relating to Microbiological Food Criteria)

[17]. D. THEVENOT, L. M. DELIGNETTEMULLER, S. CHRISTIEANS \& C. VERNOZY ROZAND. Prevalence of Listeria monocytogenes in 13 dried sausage processing plants and their products. International Journal of Food Microbiology. 102, 85-94, (2005)

[18]. H. DASKALOV, J. MOMFRE \& N. J. SOFOS. Survival and growth of Listeria monocytogenes on sausage formulated with inoculated and stored rework product. Food Control .17, 981-986, (2006)

Ljubica TRAJKOSKA, Maja TRAJANOSKA, Biljana TRAJKOVSKA, Ljupche KOCHOSKI, Vesna KARAPETKOVA-HRISTOVA, Good hygiene practices as an important program for safety of final products, Food and Environment Safety, Volume XX, Issue 1 - 2021, pag. 49 - 52 